\title{
THE PERSONAS METHOD. A TOOL FOR COMMUNICATING DATA FROM VISITOR STUDIES
}

\section{WERNER SCHWEIBENZ - STÉPHANIE WINTZERITH}

\section{ABSTRACT/ABSTRAKT:}

The paper provides an introduction to the personas method, a tool for the communication and application of complex and abstract data from visitor studies. Personas are data-based yet fictitious characters representing a specific group of visitors. They are developed in order to assist the staff in decisionmaking. This paper offers some theoretical background and describes the steps for designing and using personas, including the analysis and preparation of visitor data as well as the creation of personas with two examples. Finally, it explains how to work with personas.

\section{Metoda modelování postav (personas). Praktický nástroj získávání informací ze studií návštěvnosti}

Příspěvek poskytuje úvod do metody modelování postav (personas), která se využívá jako nástroj pro získávání a aplikaci komplexních a abstraktních dat ze studií návštěvnosti. Postavy (personas) jsou fiktivní bytosti založené na datech ze studií, které reprezentují jednotlivé specifické skupiny návštěvníků. Jsou vytvářeny za účelem pomoci odpovědným osobám $\mathrm{v}$ rozhodovacím procesu. Tento prríspěvek prezentuje některá teoretická východiska a popisuje jednotlivé kroky při navrhování a využívání modelových postav, včetně analýzy a prípravy dat návštěvnosti, a dokládá vytváření modelových postav na dvou př́kladech. Nakonec uvádí vysvětlení práce s modelovými postavami (personas).

\section{KEYWORDS/KLÍČOVÁ SLOVA:}

museology - museum - visitor visitor study - communication persona

muzeologie - muzeum - návštěvník studie návštěvnosti - získávání informací - modelová postava (persona)

\section{INTRODUCTION}

Piet, Mieke and Gust are the most well-known visitors of the Gallo-Roman Museum in Tongeren, Belgium. Each and every staff member could spot them out of a large crowd. The staff knows what they like and need, what they are looking for or interested in. It also knows how to handle their requests. And yet neither Piet nor Mieke nor Gust have ever set a foot in the museum, for a good reason: they do not exist. Not really, that is: they are no real persons but so-called personas.

Piet, Mieke and Gust embody the findings of visitor research carried out in the museum. For many people, statistics are difficult to grasp and remember, let alone to use and implement, but they can easily figure out how different individuals would react in a particular situation. Instead of presenting the quantitative data only in a report full of statistics, the museum went one step further and created personas out of this set of data. Personas are essentially tools for communication. As representatives of the most important visitor groups, Piet,
Mieke and Gust are now integrated in the decision-making process of the museum. They "speak" for their "fellow-visitors" and serve as pattern for the development of new exhibitions and offers. The whole museum became truly visitor-oriented with such an overwhelming success that the Gallo-Roman Museum in Tongeren was honoured with the European Museum of the Year Award in 2011.

Though the personas method is a natural and really useful complement to visitor research, it has still to be embraced by museums. The aim of this paper is to raise awareness and to provide the museums with the adequate know-how. Personas will first be presented in the light of their communicative characteristics, followed by a short introduction to the theoretical models. The next sections are dedicated to the data analysis and processing and to a short insight into the combination of facts and fiction. The core of the creation process will then be sketched and applied in an example of our own. Finally, the last section will show how to work with personas.

\section{A practical communication tool: The personas method}

There is more visitor and user ${ }^{1}$ data available than ever before, but at the same time we are facing

1 When we refer to visitors, we are usually referring to both in-person visitors and to online visitors (users). For reasons of readability we will address visitors only. In citations, the term "user" was left unchanged as "visitor" in many cases. 
the challenge to make this data "usable". Data gathered through visitor research is much more valuable when processed into some data that can be understood, shared and memorized. ${ }^{2}$ This is a general issue for all kinds of visitor studies: data is collected, analysed, extracted, processed and presented in reports - and those reports would be full of useful information if they were read at all. ${ }^{3}$ It would thus be highly profitable to develop other tools apart from the reports to communicate the findings and insights from visitor studies. This is crucial in order to avoid any interference of personal experiences and other biases or any loss of clarity that might occur in the communication process.

\section{Obviously, organisations -}

including museums - need visitor-oriented services and products. However, museum staff has often a very different understanding of their target groups or visitors according to personal perspective or individual field of work and experience. Having several understandings of whom they are developing the services or products for inside one institution highly increases the likelihood to fail. ${ }^{4}$ In order to avoid such failure, the organisation needs to work on a common and shared understanding of its visitors. To do so, it needs an effective tool "to communicate a picture of the people who are using the service." 5

\footnotetext{
2 MULDER, Steve and Ziv YAAR. The User is Always Right. A Practical Guide to Creating and Using Personas for the Web. Berkeley: New Riders, 2007, pp. 13f.

3 PRUITT, John and Tamara ADLIN. The Persona Lifecycle. Keeping People in Mind Throughout Product Design. Amsterdam: Elsevier, 2006, p. 8; NYSTRÖM, Viveca and Linnéa SJÖGREN. The persona method. In NYSTRÖM, Viveca and Linnéa SJÖGREN. An Evaluation of the Benefits and Value of Libraries. Oxford: Chandos, 2012, p. 102.

4 PRUITT, John and Tamara ADLIN. The Persona Lifecycle. Keeping People in Mind Throughout Product Design. Amsterdam: Elsevier, 2006, p. 7.

5 NYSTRÖM, Viveca and Linnéa SJÖGREN. The persona method. In NYSTROM, Viveca and Linné SJÖGREN. An Evaluation of the Benefits and Value of Libraries. Oxford: Chandos, 2012, pp. 99f.
}

This is where the personas come into play. According to Lene Nielsen, ${ }^{6}$ the purpose of personas is to put the museum staff in the shoes of the visitors and to give the staff an idea about what visitors need and how they might use the yet to be designed product or service. The personas serve as representatives of the visitors during the development process of services/offers/products. ${ }^{7}$ Personas can be defined as follows: "Personas are fictitious, specific, concrete representations of target users. [...] Personas put a face on the user - a memorable, engaging, and actionable image that serves as a design target. They convey information about users to your product team in ways that other artifacts cannot."

This method creates an image of the visitors which the staff can keep in mind. In this way, personas "humanize vast and disparate data sources by capitalizing on our ability to remember details about individual people". ${ }^{9}$ Psychological research indicates that we use representations of other people's mental states on a conscious and subconscious level in order to predict or understand their beliefs, goals and behaviour on both personal and general levels. ${ }^{10}$ For this reason, even fictitious personas representing "real people" are a helpful communication tool.

To achieve this humanisation, the personas method uses engaging descriptions of visitors by including information about their social background, their psychological

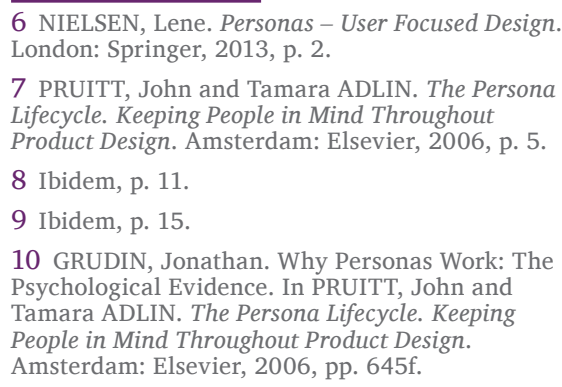

characteristics, and their emotional relationship with the focus area. ${ }^{11}$ This is a specific quality of the method as it adds credibility to the representations of visitors and supports the process of putting these representatives into the centre of decisions. As Lene Nielsen states: "To work with personas requires a broad understanding of the entire lifeworld of the user. The one reading the persona description must be able to understand and get engaged in the persona even though it is just a description in text and images. This requires that the information presented can create a level of involvement." ${ }^{\prime 2}$ By making data about visitors memorable and engaging, the personas method supports the communication in teams and with staff because it puts these representations at the centre of focus and guarantees that everybody speaks the same language. ${ }^{13}$ In this way, with personas "a common and aligned understanding is created that is shared among the project team". ${ }^{14}$ This shared understanding forms the basis of a successful communication within the project and therefore contributes to its successful realisation.

After describing the communicative aspects of personas, we will take a closer look at the method and its application, first focussing on the theoretical foundations.

\section{An introduction to the personas method}

Personas originate in user profiles that were used in marketing. In the 1990s, the concept was adapted to software development. Allan Cooper popularized it in his 1999

\footnotetext{
11 NIELSEN, Lene. Personas - User Focused

Design. London: Springer, 2013, p. 16.

12 Ibidem, p. 5

13 A life of their own. Museum visitor personas penetrating the design lifecycle of a mobile experience. In Proceeding CHI EA 2013 CHI 2013 Extended Abstracts on Human Factors in Computing Systems. New York: ACM, 2013, p. 550.

14 NIELSEN, Lene. Personas - User Focused Design. London: Springer, 2013, p. 5.
} 
book The Inmates are Running the Asylum. Why High-tech Products Drive Us Crazy and How to Restore the Sanity. Over the years, a variety of approaches were developed, ${ }^{15}$ all with a focus on information and communication technology (ICT). As a field of research, the personas method is still under development. Therefore, up to now, "there is no unilateral understanding of the application of the method or a definition of what a persona description is". ${ }^{16}$ This means that the above-mentioned definition is but one out of several possibilities. Even more so, the state of the art offers no unified or generally accepted persona theory. There are several methodologies described in English language ICT literature. Lene Nielsen $(2013)^{17}$ has identified the following approaches to personas:

- the Goal-Directed Perspective

- the Fiction-Based Perspective

- the Role-Based Perspective

- the Engaging Perspective

Table 1 provides an overview on the different approaches. ${ }^{18}$

As Nielsen ${ }^{19}$ points out "there is no one right way to work with this method but many different ways". This provides also flexibility in combining the different approaches in a way that best fits to the project in which personas are applied. This is especially important when the method is transferred to a new and

15 See COOPER, Alan. The Inmates are Running the Asylum. Indianapolis: Sams, 1999; MULDER, Steve and Ziv YAAR. The User is Always Right. A Practical Guide to Creating and Using Personas for the Web. Berkeley: New Riders, 2007; NIELSEN, Lene. Personas - User Focused Design. London: Springer, 2013; PRUITT, John and Tamara ADLIN. The Persona Lifecycle. Keeping People in Mind Throughout Product Design. Amsterdam: Elsevier, 2006; SCHWEIBENZ, Werner. Zielgruppenorientiertes Informationsdesign mit Personas. Information - Wissenschaft \& Praxis, 2004, vol. 55, no. 2, pp. 151-156.

16 NIELSEN, Lene. Personas - User Focused

Design. London: Springer, 2013, p. 14.

17 Ibidem.

18 For details see NIELSEN, Lene. Personas - User Focused Design. London: Springer, 2013, pp. 14-16.

19 Ibidem, p. 7.

\begin{tabular}{|c|c|c|c|c|}
\hline Approach & $\begin{array}{l}\text { Goal-Directed } \\
\text { Perspective }\end{array}$ & $\begin{array}{l}\text { Fiction-Based } \\
\text { Perspective }\end{array}$ & $\begin{array}{l}\text { Role-Based } \\
\text { Perspective }\end{array}$ & Engaging Perspective \\
\hline Promoter/s & Alan Cooper & Donald A. Norman & $\begin{array}{l}\text { John Pruitt und } \\
\text { Tamara Adlin }\end{array}$ & Lene Nielsen \\
\hline Literature & Cooper (1999) & Norman (2008) & $\begin{array}{l}\text { Pruitt \& Adlin } \\
(2006)\end{array}$ & Nielsen (2013) \\
\hline $\begin{array}{l}\text { Field of } \\
\text { application }\end{array}$ & $\begin{array}{l}\text { Development } \\
\text { of software and } \\
\text { complex technical } \\
\text { products }\end{array}$ & $\begin{array}{l}\text { Development } \\
\text { of products and } \\
\text { software }\end{array}$ & $\begin{array}{l}\text { Development } \\
\text { of software, } \\
\text { Persona } \\
\text { lifecycle }\end{array}$ & $\begin{array}{l}\text { Development of } \\
\text { software }\end{array}$ \\
\hline Focus & $\begin{array}{l}\text { Focus on goals of } \\
\text { users and their use } \\
\text { of the products }\end{array}$ & $\begin{array}{l}\text { Empathic focus on } \\
\text { the design process }\end{array}$ & $\begin{array}{l}\text { Focus on } \\
\text { behaviour while } \\
\text { using a product }\end{array}$ & $\begin{array}{l}\text { Product development } \\
\text { with a focus on } \\
\text { empathic and social } \\
\text { aspects }\end{array}$ \\
\hline Basis / source & Data & $\begin{array}{l}\text { Intuition and } \\
\text { personal experience }\end{array}$ & Data & $\begin{array}{l}\text { Data and fictional } \\
\text { elements }\end{array}$ \\
\hline
\end{tabular}

Table 1: Overview on persona approaches

different field of application, as in our specific case to museums.

For the field of museology, to the best of our knowledge, there are no publications on persona theory. Our approach is drawing mostly on the Role-Based Perspective ${ }^{20}$ and the Engaging Perspective ${ }^{21}$ as theoretical foundation and on our practical experience from applying personas to museum projects.

Several institutions have already used the personas method, a few of them have published their experiences, such as, however without disclosing which theoretical or practical approach they followed:

- the Acropolis Museum, Athens, ${ }^{22}$ - the Getty Audience Experience Team of the J. Paul Getty Trust Web Group, ${ }^{23}$

20 PRUITT, John and Tamara ADLIN. The Persona Lifecycle. Keeping People in Mind Throughout Product Design. Amsterdam: Elsevier, 2006.

21 NIELSEN, Lene. Personas - User Focused Design. London: Springer, 2013.

22 A life of their own. Museum visitor personas penetrating the design lifecycle of a mobile experience. In Proceeding CHI EA 2013 CHI 2013 Extended Abstracts on Human Factors in Computing Systems. New York: ACM, 2013, pp. 547-552. 23 LEE, Ahree and Emily LYTLE-PAINTER. Getting Personal: Creating Personas for Museum Visitors. In The annual conference of Museums and the Web, April 8-11, 2015, Chicago, IL, USA [online]. [accessed 2018-01-31]. Available from www: <http://mw2015.museumsandtheweb.com/ proposal/getting-personal-creating-personas-for-museum-visitors/>
- the Jewish Museum Berlin, ${ }^{24}$

- the Museum of Science, Boston, ${ }^{25}$

- Santa Cruz Museum of Art \& History, ${ }^{26}$

- the Tate. ${ }^{27}$

Several steps are necessary to construct a data-driven persona, as described in the literature. Figure 1 illustrates the framework of personas. To keep it simple, the creation process and its stages are summed up as "persona concept". ${ }^{28}$ However, there is no general

24 WENZEL, Mirjam. Towards an Online Platform for Jewish History and Culture. The mid-term online strategy of the Jewish Museum Berlin. In Blogerim. From the corridors of the Jewish Museum Berlin [online]. 2015 [accessed 2018-01-31]. Available from www: <http://www.jmberlin. de/blog-en/2015/06/online-platform/>

25 IACOVELLI, Stephanie. Using Personas in the Design Process of Digital Exhibit Interactives. Creating Museum Media for Everyone (DRL-1114549) [online]. Boston: Museum of Science, 2014 [accessed 2018-01-31]. Available from www: <http://openexhibits.org/wp-content/uploads/ papers/CMME\%20Personas.pdf $>$.

26 SPELLERBERG, Marty, Elise GRANATA and Sarah WAMBOLD. Visitor-first, mobile-first: Designing a visitor-centric mobile experience. In The annual conference of Museums and the Web, April 8-11, 2016, Los Angeles, CA, USA [online]. [accessed 2018-01-31]. Available from www: $<$ http://mw2016.museumsandtheweb.com/paper/ visitor-first-mobile-first-designing-a-visitor-centric-mobile-experience/>

27 TASICH, Tiana and Elena VILLAESPESA. Meeting the Real User: Evaluating the Usability of Tate's Website. In Museums and the Web 2013. Proceedings from the annual conference of Museums and the Web 2013. April 17-20, 2013, Portland, OR, USA [online]. Toronto, Ontario: Archives $\&$ Museum Informatics [accessed 2018

-01-31]. Available from www: < http://mw2013. museumsandtheweb.com/paper/meeting-the-real-user-evaluating-the-usability-of-tates-website/ $>$. 28 For details see section Creating the personas. 


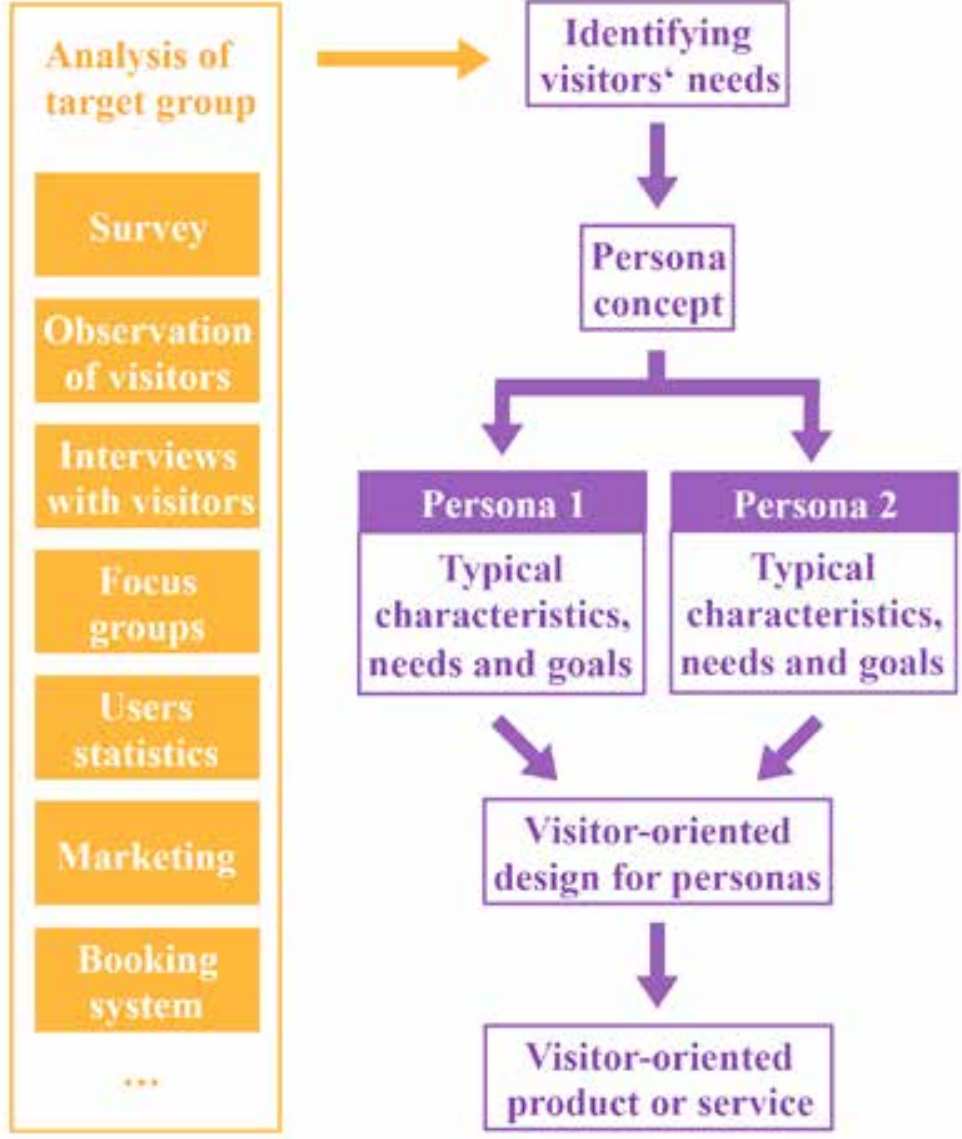

Figure 1: The framework for personas

understanding on a definite number or sequence of the steps, nor of the degree of details implied.

A method for creating and developing personas will be described further on in this article. But before starting with the persona creation, it is necessary to take a closer look at the foundation: the data.

\section{Analysing the visitor data}

Museums gather a lot of data about their visitors, some of it on purpose, some of it rather incidentally. Unfortunately, some (most?) of this data remains unused, partly for want of interest, partly because of a lack of know-how. The three main sources of information are the booking system, the users' statistics for all digital devices, websites, apps and so on, and finally the findings of visitor studies. Each museum, even institutions which do not explicitly implement visitor research, has at least a certain set of data at its disposal from which it can draw useful information for the design of personas.

The booking system of the museum, depending on its structure, has more to offer than plain ticketing. Though often neglected as a source of information other than counting visitors and entrance fees, it holds basic data about audiences that has to be processed and carefully analysed. For example, the categories of entrance fees can give hints about the age of visitors (usually children/ youths, regular and senior), the composition of the group of visitors (family tickets) or sometimes about the social structure of the audience (discount/free entrance for local communities, students, unemployed, disabled people, specific professional categories like teachers etc.). Combined tickets with other museums or exhibitions as well as museum cards or cultural passes inform about cultural interests of the visitors who buy or hold them, professional cards (mainly museum associations or ICOM) give evidence of the share of colleagues in the audiences. Sometimes visitors are asked for their postal code to identify the museum's catchment area. Groups and schoolchildren indicate an address of their contact person, hence stating where they come from. They also indicate the size of the group and for pupils the class they are in, which workshop or guided tour they want etc. All this information, while closely looked at, already reveals very much about the structure of the audiences, some of their interests and habits.

Other statistics are generated inside the museum, such as the pattern of use of audio guides for instance. When properly programmed, they can sum up statistics about the language used, the numbers typed in - and thus information about the corresponding objects/artworks looked at - the time spent listening, the explanations that were broken off or skipped and so on. The same kind of user's statistics can be made available nowadays for many digital devices on display (touch screens, interactive exhibits) or used for education purposes (apps, audio guides etc.). While put in the "right" shape, all this gives precious insights into the visitors' behaviour inside the exhibitions. Obviously, websites also produce a large amount of data that could be analysed in order to know more about their users: number of users, number of clicks, pages looked at, origin of the link to the websites and so many more. 
However, visitor studies are the privileged source of information when structured, coherent and detailed data is needed. ${ }^{29}$ The greatest advantage of those studies, commonly taking the form of a survey but applying also to the other research methods including qualitative approaches, is (ideally) that they are tailor-made for the museum and the topics they were designed to answer. As such, they serve a particular purpose and gather specific information in a suitable shape. The collected data usually encompasses characteristics of audiences such as socio-demographics (i.e. age, gender, education, profession, place of residence, class level for pupils for example), affinity to the museum and context of the visit (first/frequent visit, favoured type of museum, frequency of museum visits, composition of the visiting group, etc.) as well as any other relevant information. Circumstances of the visit (source of information, motivations), behaviour inside the exhibitions (visited galleries, use of interactives, favourite objects, guided tours, etc.) are part of the findings. A visitor study is also an excellent instrument for collecting data about the audiences' expectations, visit experience and satisfaction.

Qualitative data can be found in visitor books, comments and feed-back facilities, as well as collected through visitor studies (open ended questions in a survey, interviews with visitors, focus groups etc.) and observations. Though usually not striving for representativity, it is nonetheless extremely useful for a better understanding of audiences. It provides explanations, reasons, opinions and background

29 WINTZERITH, Stéphanie. Streifzug durch die Welt der Besucherforschung. In Das Publikum im Blick. Besucherforschung als Impuls für besucherorientierte Museumsarbeit. Hagen: für besucherorientierte Museumsarbeit. Hage Freilichtmuseum Hagen, 2014, pp. 44f. information in the visitors' own wordings. Where quantitative data aggregates, sums up and unifies in a particular frame, qualitative data differentiates, nuances and gives way to the freedom of individual expression. Hence qualitative data is a powerful carrier of ideas and communication.

Though all these sources provide equally valuable data, visitor research is often favoured for the design of personas because its data is generally less fragmented and enables to match purposefully structured socio-demographics with expectations, behaviour, needs, goals and interests.

Especially the latter three are essential to establish persona profiles. Therefore, the following paragraphs focus on findings from visitor studies.

\section{Preparing the visitor data}

How to deal with this avalanche of words, figures, pie-charts and statistical tables? First and foremost, it is crucial to differentiate the relevant data from the less relevant. This is only possible with a clear idea of what's needed, which implies a precise formulation of the aims intended for the personas and their future application in/for the museum. In other words, you have to know exactly what you need the personas for. Once the aims are settled, the next step is to identify or define the (main) target group(s) accordingly.

This is when data comes in: relevant data is the one which either provides information about a target group, or helps defining it. All available data has to be gathered and scanned in order to select the one connected to the target group(s). At this point, dealing with the data is intertwined with the actual process of creating a persona: it is a part of the idea-generating phase. The relationship between the data and the considered target group(s) can be compared to the casting for a movie. In the same way as the director has to find an actor who fits into the character of the play, you have to find the data matching with the personas intended for the target group(s). When facing a choice of several "candidates", you'll pick the most suitable set of data but you might also enrich the definition of your target group(s) according to the available data - like a director adapting the script to the chosen actor. Should important data prove to be outdated or missing, it would have to be collected anew wherever possible, with a dedicated visitor survey for example.

Having selected, and if need be, completed the relevant data, the next step is to brush a portrait of the target group(s) as detailed as necessary and as realistic as possible. Statistics give an informative basis, especially the distribution for each variable and even more so the cross-tabulations resulting from surveys. A cross-tabulation consists in crossing the information of two variables and calculating the relative distribution from one another. For example, the findings of a survey show that the audience holds $46 \%$ women and $54 \%$ men (distribution of variable 1), and that $70 \%$ of the audience read at least some texts while $30 \%$ do not (distribution of variable 2 ). Crossing variables 1 und 2 means looking at the reading patterns for men and women separately. The results of this statistical operation are interpreted in terms of gender-specific reading habits and interests for the presented contents in this particular museum. Cross-tabulation may for example indicate that $81 \%$ of the men read at least some texts and $19 \%$ do not, while the women are less interested since only $57 \%$ of them 
read texts and $43 \%$ do not. Hence the target group "text-readers" would predominantly consist in men, which gives a valuable clue for choosing the gender of the main persona representing it.

As an alternative to such cross-tabulations, it is also recommended to cross data from different sources so as to describe the target group(s) as precisely as possible. For example, the booking system records that $2 \%$ of the individual visitors take a guided tour and $21 \%$ of the adult visitors use an audio guide, half of which choosing the English language version. However, there is no information about the percentage of locals and tourists who visit the museum because it is not collected by the museum staff. So a second data source has to come in to fill this gap. In order to best describe the target group "tourist visitors", search the city's tourism statistics for the main provenance countries of tourists and their propensity to visit cultural sites such as museums. Transferring this information to the target group gives hints about the languages needed for the audio guide and the guided tours as well as the flyers presenting the museum to tourists and thus some clues for the design of the personas.

A close analysis as well as the crossing of the relevant data enable you to develop a kind of matrix or cluster and to shape the most frequent or the most realistic characteristics for each target group. Those clusters feed the decision-making process while allocating characteristics to the personas in the sense of a data-based design, even though personas remain the result of objective data-based decisions as well as subjective decisions equally. Actually, personas are a combination of facts and fiction, as commented in the following section.

\section{Facts and fiction}

The above mentioned quantitative and/or qualitative data is the fundamental basis for data-driven personas. However, no matter how broad and comprehensive your data might be, you will unavoidably encounter some gaps or blanks in the process of creating personas. The reasons can be manifold. A lack of data usually stems from constraints in time and money or from other factors such as limited access to specific audiences or target groups. As a consequence, should we base our personas exclusively on the available data, we would inevitably produce blind spots in the profiles of the personas we created. When the facts are not sufficient to cover all the scope needed, we use fiction to fill the gaps and complement the look and feel of the personas. This is important as, on the one hand, personas embody vast amounts and disparate sources of data; ${ }^{30}$ on the other hand, personas have to be memorable, engaging, and actionable. ${ }^{31}$ To achieve this, personas have to be more than a collection of facts. They should be compelling stories that unfold over time in the mind of the team. ${ }^{32}$

This means that personas are a combination of facts and fiction. Their fictional part serves to make their profile complete and to form a round figure or character. The fictional elements are added to provide "background information, frames of reference, and details that make the personas credible,

\footnotetext{
30 PRUITT, John and Tamara ADLIN. The Persona Lifecycle. Keeping People in Mind Throughout Product Design. Amsterdam: Elsevier, 2006, p. 15.

31 Ibidem, p. 11; SCHWEIBENZ, Werner. Know thy visitors. Personas for visitor-centered museums. In The International Journal of the Inclusive Museum, 2008, vol. 1, no. 2, pp. 104f

32 PRUITT, John and Tamara ADLIN. The Persona Lifecycle. Keeping People in Mind Throughout Product Design. Amsterdam: Elsevier, 2006, p. 37.
}

memorable and actionable". ${ }^{33}$ This has nothing to do with creating personas out of thin air or "persona confabulation" 34 as critics of the method claim. Actually, it is an integral part of method: "The persona descriptions balance between data and knowledge about real applications and fictitious information that, as mentioned, is intended to create empathy." 35 Combining facts and fiction contributes to achieving the goal of communicating insights about visitors. From our perspective, the drawbacks of the method are very limited compared to having to communicate complex data in reports that are hard to read and difficult to understand for the members of your institution. Moreover, "even people who have read reports on users end up with an ongoing conception of the user based on a few facts and a loose set of assumptions, all tinted with personal experiences and biases." 36 Empathy and understanding are central aspects as the personas method is first and foremost a communication tool. It is certainly true that "tools have affordances, and [that] they lead to certain types of usage". ${ }^{37}$ But this applies to any kind of instrument you might use in your projects. Being aware of it will prevent you from making gross mistakes. As a consequence, you have to take the following aspect into account while working with personas: "However, it is also important to remember that personas can never fully express or represent the data in the same way it is expressed in

\footnotetext{
33 SCHWEIBENZ, Werner. Know thy visitors. Personas for visitor-centered museums. In The International Journal of the Inclusive Museum, 2008, vol. 1, no. 2, p. 105.

34 PORTIGAL, Steve. Persona non-grata. In Interactions, 2008, January + February, p. 73. 35 NIELSEN, Lene. Personas - User Focused Design. London: Springer, 2013, p. 16. 36 PRUITT, John and Tamara ADLIN. The Persona Lifecycle. Keeping People in Mind Throughout Product Design. Amsterdam: Elsevier, 2006, p. 8. 37 PORTIGAL, Steve. Persona non-grata. In Interactions, 2008, January + February, p. 73.
} 
the original sources, and that this is the point of the personas. Rather, personas will help you communicate the essential and helpful information the data contains. The danger that some aspects of the personas may misrepresent some aspects of the data is outweighed by the guarantee that the personas will convey important and data-driven information to your product team." 38

Knowing the potential pitfalls inherent to the personas method also helps to implement and use them properly as what they are, i.e. a constructed communication instrument. Having said this, it is now time to look into the way personas are designed and to follow the adequate steps for creating them.

\section{Creating the personas}

From the methodological perspective, a persona is the result of a series of deliberate, but not haphazard decisions. If more than one options are under consideration, the most likely or the most realistic one will be chosen. This decision is so to say a "reason-based arbitrary" one, comparable to the resolution about which target group to focus on or which data to use. The selection of a persona's characteristics is a subjective, "soft" decision, which can be explained and justified but which can also be questioned for good reasons. Therefore, two project teams working with the same data as a basis and the same focus in creating personas could nevertheless come up with different selections and solutions, in short with different personas. This does not invalidate the method since personas are understood as an instrument, and as such, could take several implementations although they serve the same purpose.

38 PRUITT, John and Tamara ADLIN. The Persona Lifecycle. Keeping People in Mind Throughout Product Design. Amsterdam: Elsevier, 2006, p. 195.
Having selected the relevant data, several steps are required to develop data-driven personas. The following seven phases are recommended although they might be adapted according to the scope and size of the project.

\section{From the data, identify the personas for your target groups}

Decide what kind of personas you need and how many. This step depends on the following aspects:

- the size and complexity of your project,

- the kind of data you have available and

- the target groups you want to include in the personas design process.

These decisions are closely related to the available data. Usually, you start with a cast of characters like the one in a play.

The ideal number of personas for a project is an issue that is unresolved and still controversially debated in the literature. In practice, human memory puts limits to the number of personas we can handle, as we find it difficult to distinguish them and remember details about them if we have to deal with too many of them. So, for practical reasons, it is better to keep the number of personas small. ${ }^{39}$ As a rule of thumb, five or six personas in a project should be enough. ${ }^{40}$

A good way to balance the personas is to create them as contrasting pairs within various parameters, ${ }^{41}$ e. g. young vs. old, single visitor vs. family,

39 Ibidem, p. 169; NYSTRÖM, Viveca and Linnéa SJÖGREN. The persona method. In NYSTRÖM, Viveca and Linnéa SJÖGREN. An Evaluation of the Benefits and Value of Libraries. Oxford: Chandos, 2012, p. 107.

40 NIELSEN, Lene. Personas - User Focused Design. London: Springer, 2013, p. 9.

41 Ibidem, pp. 38f. text reader vs. non-reader. Such contrasts - based on the available data - provide the personas with characteristic features. Moreover, they allow quick judgements on how supporting the needs, goals and interests of one persona might affect her counterpart. In some cases, the effects on the contrasting persona can be viable, in others not. Hence you can either fulfil the requirements of both personas equally or make a clear decision for one of them.

2. Define the individual persona's needs, goals, and interests

Each persona has specific needs, goals and interests that have to be fulfilled in order to make her feel comfortable. Needs include basic aspects as seating, rest rooms, orientation in the exhibit and the building. Goals can be, for example, spending a nice afternoon with friends and family or learning something new. Interests relate to our visitors' individual preferences which are closely related to education and previous knowledge. The data to identify needs, goals and interests is based on your surveys and can be enriched by insights from general audience research.

\section{Define the constraints the persona faces}

Depending on the circumstances it might be reasonable to add constraints to an individual persona. For example, if you design personas who represents elderly persons it can be useful to equip them with certain constraints that are typical for this age group. In this way you can remind your staff of restrictions and limitations they might not be aware of. Another important aspect regards people 
with disabilities..$^{42}$ Personas can help to customize museum products and services to their specific needs.

\section{Add personal and social aspects to the persona}

Personal aspects increase both the usefulness and credibility of a persona as they illustrate her character by including traits such as attitudes, aptitudes, behaviour, habits and educational background. In part these qualities, for example education, are based on data, in part they can be taken from general audience research, and in part they are fictional (see the section Facts and fiction). The level of detail is an important issue for personas. On the one hand, details should be elaborated enough "to be able to enter into the lives of the users" ${ }^{\prime 3}$ or visitors. However, it should not be too detailed in order to be recalled by the teams working with personas. The art in designing personas is to keep this balance.

Without any doubt, a persona has to be carefully portrayed in order to be credible and convincing as a user representation. This process includes giving her a name and a face. Choosing the name is something you should do with care since names can carry associations or even worse, make a persona become a caricature instead of a character. ${ }^{44}$ The name should neither be extravagant nor stupid, but a distinctive mark of identification because you are going to use it every time you refer to the persona. In addition, the names of the personas should be so different from each other that you

42 SLATIN, John M. and Sharron RUSH Maximum Accessibility. Making your Web Site more usable for everyone. Boston: Addison-Wesley Professional, 2003. Chapter 7 User Experiences: Museums on the Web.

43 NIELSEN, Lene. Personas - User Focused Design. London: Springer, 2013, p. 4.

44 MULDER, Steve and Ziv YAAR. The User is Always Right. A Practical Guide to Creating and Using Personas for the Web. Berkeley: New Riders, 2007, pp. 168-170, 175. can easily distinguish the personas. Another important step is to give a face to the persona, that is to say, choosing a picture that represents her. As pictures can also convey messages about the persona, be considerate when choosing it. It has to fit both the personality traits you described for the persona and the social aspects.

Social aspects can enhance the context of the visit or use (e. g. alone, in company) and provide opportunities for scenarios to include sequences of interaction. In addition, the social aspects are an ideal opportunity to introduce additional characters as "assistants" that accompany the persona in general, in a specific task or a scenario. These assistant figures can serve several purposes:

- illustrate the persona's experience by mirroring or contrasting her behaviour,

- reflect the persona's experience by serving as a counterpart for communication,

- assist a persona in a task with specific knowledge or experience the persona has yet to acquire,

- adding different perspectives to the situation the persona is in.

\section{Document the personas (using} a skeleton and a description)

Each persona consists of two descriptive parts. The first is the so-called skeleton, which is basically a summary of the persona's characteristics, usually in the form of a table for easy scanability. It is followed by a textual description of the persona which can vary depending on the scope of the project. In general, important parts of the persona description are aspects such as:

- information needs and goals of the persona,

- service needs of the persona,
- media use of the persona.

For details see section Examples for personas.

\section{Validate the personas}

After creating a skeleton and a description for each persona, it is time to validate the persona. The review consists in a careful reading of both skeleton and description, checking the completeness, the integrity and the credibility of the persona. This is best done in a team while reading aloud. The guiding questions can be: "Do you recognise this person? Does this sound at all like somebody you know?"45 It can also be done by groups of two people who describe the persona and ask for feedback. ${ }^{46}$ If you happen to find flaws or gaps, you have to do a revision of the personas to make them consistent. ${ }^{47}$ This is important since in the end, personas have to succeed in becoming like real people in our minds. ${ }^{48}$

\section{Develop the personas}

After working with personas for some time, you might find it necessary to add information, to clarify the persona descriptions or to make adaptations due to new data and so on. Personas are never finished but develop over time. This means the descriptions should be revised regularly, approximately once a year ${ }^{49}$ or at least every few years. ${ }^{50}$ There is no hard rule when

45 NYSTRÖM, Viveca and Linnéa SJÖGREN. The persona method. In NYSTROM, Viveca and Linnéa SJÖGREN. An Evaluation of the Benefits and Value of Libraries. Oxford: Chandos, 2012, p. 110.

46 NIELSEN, Lene. Personas - User Focused Design. London: Springer, 2013, p. 11.

47 Ibidem, p. 13.

48 A life of their own. Museum visitor personas penetrating the design lifecycle of a mobile experience. In Proceeding CHI EA 2013 CHI 2013 Extended Abstracts on Human Factors in Computing Systems. New York: ACM, 2013, p. 550.

49 NIELSEN, Lene. Personas - User Focused Design. London: Springer, 2013, p. 11.

50 NYSTRÖM, Viveca and Linnéa SJÖGREN. The persona method. In NYSTRÖM, Viveca and Linnéa SJÖGREN. An Evaluation of the Benefits and Value of Libraries. Oxford: Chandos, 2012, p. 103. 
an update or revision is necessary, it depends on how you are using the personas and on the available resources.

Following these steps, personas can be successfully designed. The following section presents two examples for personas. For the practical application of personas, you need scenarios, that is to say short narratives, which serve as vehicles for the practical appliance of personas. This process will be presented in the section Working with the personas.

\section{Examples for personas}

The personas presented in this section were created for teaching purposes. The data was kindly provided by the Staatliche Museen zu Berlin - Stiftung Preußischer Kulturbesitz (National Museums in Berlin, Prussian Cultural Heritage Foundation) and is part of the foundation's audience report series. ${ }^{51}$ From this report, the data for the Pergamon Museum was selected for further analysis and processing. However, the Pergamon Museum itself was neither involved in the development nor applied these personas. Nevertheless, for the sake of reference, from now on they are called the Pergamon Personas.

A survey conducted in the Pergamon Museum in November 2002 produced a sample of 440 visitors, of which $53 \%$ are women and $47 \%$ men. Out of this set of data, the two most important target groups were selected for developing the Pergamon Personas: the age cohorts 30-39 years (22\%) and over 60 years (21\%). The profession (55\% employed/ self-employed and $18 \%$ retired),

51 SCHUCK-WERSIG, Petra and Gernot WERSIG. Die Staatlichen Museen zu Berlin und ihre Besucher. Zusammenfassungen aus den Jahren 2001-2004. (Mitteilungen und Berichte aus dem Institut für Museumskunde, Bd. 35). Berlin: Institut für Museumskunde, 2006. education (52\% university degree and $22 \%$ high school degree), the frequency of visits (66 \% first-time visitors and $26 \%$ one to three visits a year) and the place of residence (Berlin vs. tourists from other federal states of Germany) were the selected characteristics. Two personas were designed based on this data.

Persona for the target group "age cohort 30-39 years" from another German federal state

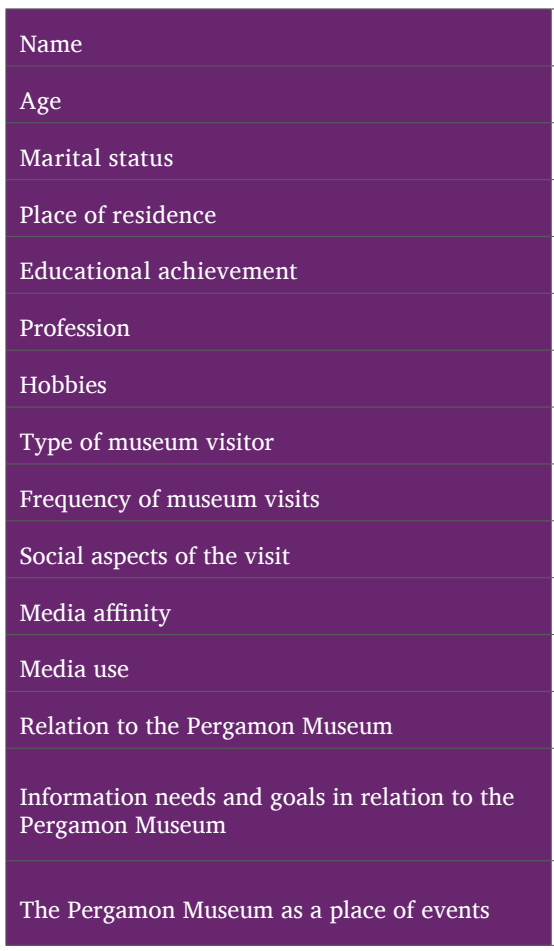

\begin{tabular}{l} 
Christian Michels \\
\hline 32 \\
Married, no children \\
Frankfurt am Main \\
\hline University degree in business administration \\
\hline Controller in a bank \\
\hline Sports, music, movies \\
\hline First-time visitor \\
\hline Once a year \\
\hline In company of his wife \\
\hline High for new media, low for traditional media \\
\hline Internet, smart phone, radio \\
\hline None \\
\hline Basic information because it is the first visit. \\
Information for preparing the visit and further \\
information after the visit. \\
\hline Non-existent \\
\hline
\end{tabular}

Table 2: Skeleton for persona Christian Michels

Information needs and goals of the persona Christian Michels:

Christian Michels works as a controller in a bank, i.e. he is a person who appreciates precise and reliable information. He makes professional trips to Berlin several times per year. He sometimes stays for the week-end, usually accompanied by his wife Karin. For the next trip, the couple plans to visit the Pergamon Museum to see the famous Pergamon Altar because they had watched an impressive TV documentary on the ancient city of Pergamon. To prepare their visit, Christian Michels does some research on the Internet. He particularly looks for specific services concerning the Pergamon Altar. He also wants to check the opening hours, the entrance fees and the current exhibitions beforehand. He finds detailed information on prices and bookings directly on the museum's homepage. 
Service needs of the persona Christian Michels:

As he and his wife are especially interested in the Pergamon Altar, Christian Michels looks for information on corresponding services. He prefers an audio guide rather than a guided tour because he wants to be flexible and free from museum tour schedules. He looks beforehand for some information offers about the Pergamon Altar, be they charged or complimentary, but he can' $t$ find anything. However, he finds some basic information about the museum as well as a floor plan on the portal of the Staatliche Museen zu Berlin. In this way, he can plan ahead of his visit which room he wants to see in addition to the Pergamon Altar itself. He also looks for the gastronomic services either in the Museums café, or in nearby restaurants, since he intends to have a light lunch with his wife Karin, concluding their visit before doing some further sight-seeing. The museum shop is of no great interest to him, neither on the spot, nor online.

Media use of the persona Christian Michels:

Christian Michels has a high affinity for the Internet and digital devices. He doesn' $t$ buy travel guides in print anymore because he values only current information which he can access any time he wants to. As a source for information, he usually sticks to Wikipedia and Wikivoyage, the travel wiki. From the articles in these wikis he has some basic knowledge on the collections which make up the Pergamon Museum (antiques, Lesser Asia and Islamic art). Most of the information he uses was found online.

In the museum he would watch an introductory movie on the Pergamon Altar if it is not too long (max. 10 to 15 minutes). In the exhibition, he expects short, precise and comprehensible texts as he does not like long and complex explanations. He reads text labels but prefers audio guides because he likes to look at the objects while learning about them. Moreover, he would enjoy interactive tools to learn more about the altar, its production and restoration. He would also be willing to stop at an information point, though if he had the choice, he would rather opt for a tablet to be more flexible.

Persona for the target group "age cohort 60plus years" from Berlin

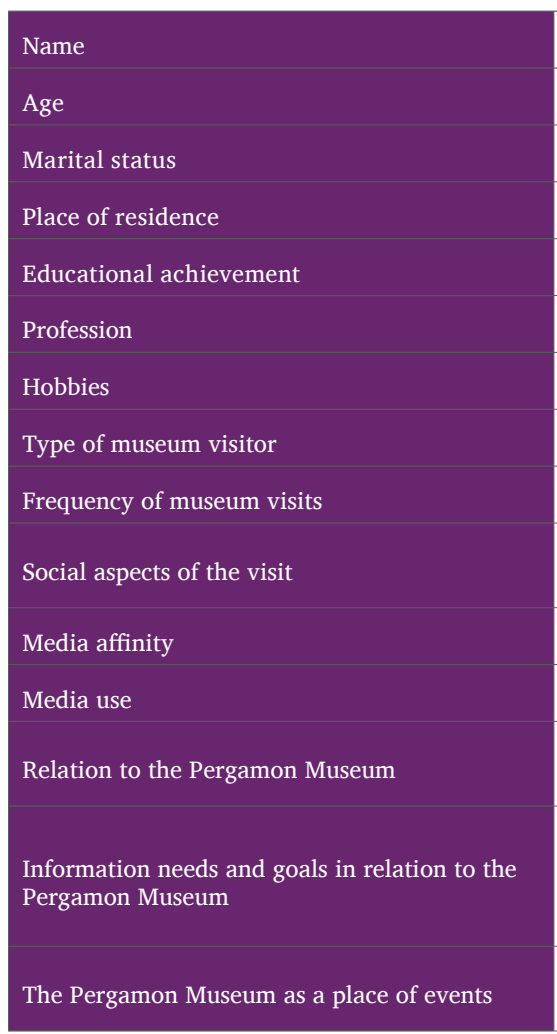

\begin{tabular}{l}
\hline Else Schultheiss \\
\hline 64 \\
\hline Divorced, children and grandchildren \\
\hline Berlin \\
\hline High school \\
\hline Retired \\
\hline Travelling, culture, arts \\
\hline Frequent visitor \\
\hline Three times a year \\
\hline $\begin{array}{l}\text { Usually in company of friends (same age), } \\
\text { occasionally in company of her grandchildren }\end{array}$ \\
\hline High for traditional media, low for new media \\
\hline Newspaper, radio, television, hardly Internet \\
\hline $\begin{array}{l}\text { Familiarity from classes at the academy of the } \\
\text { Staatliche Museen zu Berlin }\end{array}$ \\
\hline $\begin{array}{l}\text { Frequent visitors, interested in additional and broader } \\
\text { information on specific topics of permanent and } \\
\text { special exhibitions and in events related to these } \\
\text { topics }\end{array}$ \\
\hline $\begin{array}{l}\text { Familiarity from classes at the academy of the } \\
\text { Staatliche Museen zu Berlin }\end{array}$ \\
\hline
\end{tabular}

Table 3: Skeleton for persona Else Schultheiss

Information needs and goals of the persona Else Schultheiss:

As a frequent participant of the academy of the Staatliche Museen zu Berlin, Else Schultheiss is familiar with the Pergamon Museum from several classes and visits. Now she wants to learn more about the collections and staff. However, it is best to deliver such stimuli and information in a reasonable quantity and in an appropriate, comprehensible form for her. She does not like to be overwhelmed with information.

\section{Service needs of the persona Else Schultheiss:}

Else Schultheiss is especially interested in educational offers giving her food for thoughts and subject matters for exchanges with her friends (or family) accompanying her for the visit. However, they do not want to participate in programs explicitly 
labelled "for elderly people". In fact, they prefer ordinary programs, such as those of the academy for example, where participants of all age groups meet. Thanks to her regular attendance in the classes of the academy, Else Schultheiss is more or less familiar with the jargon of museum guides and tutors. Nevertheless, she prefers a simple and comprehensible language for guided tours and seminars. Concerning the educational contents, she has a preference for learning about potential connections between the collections (antiques, Lesser Asia and Islamic art). Her special interest goes to the collection of antiques. In the context of her museum visits she expects a nice café to make a break and a shop well stocked with guides, catalogues and also arts and crafts products such as replica.

Media use of the persona Else Schultheiss:

Else Schultheiss has a high affinity for traditional media, especially newspapers and radio, but also television. Her attitude towards new media is not exactly detached, but she has no real interest in it. She seldom uses the Internet, and if so for searching information about the cultural sector. She knows about the e-mail newsletter but does not use it; instead she has subscribed to the newsletter in print. In the exhibition she usually reads the different kinds of labels (master labels, subject labels, explanatory labels, etc.) in order to get all information available. She knows about the audio guide but uses it rarely as she thinks it hems the communication with her company. She prefers to talk to the docents and to her friends. Therefore, she also avoids using interactive tools in exhibitions because such devices are often designed for one user only.

\section{Working with the personas}

In order to establish the personas in your institution, they have to come alive, that means the personas have to be present in day-to-day decision making. This is achieved by using them in role-playing, i.e. when a staff member walks through a situation "in the shoes of the persona". A short textual description of a concrete situation, a so-called scenario, leads this process. This brief narrative sets the scene and the context in which one or more specific persona(s) use an offer. The focus is on the interaction of the persona and potential problems which might occur in this situation.

\section{Make the personas known in your institution}

As all the offers of the institution will eventually be custom-made according to these user representations, it is essential that the whole staff becomes familiar with the personas. Communication at an early stage within the museum is a key to acceptance and eventually success. It starts with announcing the implementation of the personas and presenting the method, subsequently it is important to keep the whole staff informed about the progress. To create and maintain interest in the institution during the design process, regular updates should be presented to the staff.

The roll-out of the personas usually starts with a workshop where the individual characters are introduced to the whole staff, the basics of the method are once more explained and it is clearly stated which aspects of the personas are based on data and which ones are not. Making the method transparent will help establishing acceptance.
The next phase is disseminating the knowledge about personas in the museum. The information is made available to all who have not yet participated in the persona work, using posters or any other appropriate communication material. From now on, the personas have to be present at all meetings and decision points. ${ }^{52}$

2. Keep the personas in the focus of decision-making

As soon as personas are included in decision-making processes, make sure they always remain the central focus of it. This will be a challenge since old habits tend to linger and your staff might now and then fall back in familiar, long established patterns. To prevent this, you can give individual team members the ownership of a specific persona and ask this colleague to act as godparent for her. In this role he or she is responsible that the persona and her needs, goals and interests are not overlooked or bypassed in any decision. As this is an official duty, the godparent has the right to speak up for the persona under his or her responsibility - and is expected to do so.

\section{Enrich your data for scenarios}

Personas are strongly connected to the museum since they are based on data collected in and by the institution, often through visitor studies. Additional information could nevertheless be helpful to provide for another background, context or situation. General data and insights on visitor behaviour from other audience researches could thus enrich the scenarios. Such data relates to typical aspects like the overall motivation for the visit, the mode of the visit (alone, in company), the patterns of movement in exhibition halls, the 
holding time of objects and texts or the occurrence of museum fatigue.

\section{Write scenarios for each persona}

Although a large part of this article is devoted to the designing of personas, their main value is not the persona itself but its application: as all instruments, they have to be put into action to be of any practical use. This is done using scenarios, i.e. short narratives, which "put personas in motion". ${ }^{53}$ These brief stories set the frame for a persona to interact with a product or to use a service provided by the museum. The persona brings her characteristic features, needs, goals and interests and acts inside the set framework. As such, the scenario is basically an evaluation. ${ }^{54}$ It can be compared to a short film, the persona is the character and the scenario is the plot that is about to unfold.

To be effective, a scenario has to be:

- understandable, that means describe a familiar or typical situation,

- told from the perspective of the protagonist: the persona,

- have a degree of importance that makes it worth telling,

- based on a real event, that is, grounded in reality or based on anecdotes from user research.

What is really important about scenarios is that they have to be short; they suggest rather than spelling it out. ${ }^{.5}$ Consequently, one or two sentences are enough to

53 MULDER, Steve and Ziv YAAR. The User is Always Right. A Practical Guide to Creating and Using Personas for the Web. Berkeley: New Riders, 2007, p. 190.

54 NYSTRÖM, Viveca and Linnéa SJÖGREN. The persona method. In NYSTRÖM, Viveca and Linnéa SJÖGREN. An Evaluation of the Benefits and Value of Libraries. Oxford: Chandos, 2012, p. 111.

55 QUESENBERY, Whitney. Storytelling and Narrative. In PRUITT, John and Tamara ADLIN. The Persona Lifecycle. Keeping People in Mind Throughout Product Design. Amsterdam: Elsevier, 2006, p. 531. set a stage for action; there is no need for in-depth analysis of the situation. If you have no experience with scenarios, it can be a good idea to formulate them on the basis of situations that have actually been observed. ${ }^{56}$

\section{Examples for scenarios}

The following examples show how the Pergamon Personas can be put into action.

Scenarios for the persona Christian Michels:

1. Christian Michels plans his visit to the Pergamon Museum from his home.

2. Christian Michels and his wife Karin enter the foyer of the Pergamon Museum and look for orientation.

3. Christian Michels uses conventional and interactive media in the exhibit.

4. Christian Michels reads texts in the exhibit.

Scenarios for the persona Else Schultheiss:

1. Else Schultheiss looks for information on services inside the museum.

2. Else Schultheiss wants to try out an audio guide.

3. Else Schultheiss wants to be comfortable in the exhibit.

4. Else Schultheiss strolls through the museum shop.

6. Role-play the scenario taking the role of the persona

The scenario comes to life when a staff member takes over the role of the persona and walks through the situation in her shoes. In the course of action, the role-player identifies how smoothly the situation can be handled,

56 NYSTRÖM, Viveca and Linnéa SJÖGREN. The persona method. In NYSTRÖM, Viveca and Linnéa SJÖGREN. An Evaluation of the Benefits and Value of Libraries. Oxford: Chandos, 2012, p. 110. what potential problems can arise, and how satisfied the persona is with the results. Usually the role-player describes in the third person (Christian Michels/he or Else Schultheiss/she) and in detail how the persona performs and how her reactions are. The results are collected in a short protocol noting the overall performance, encountered problems and potential solutions or new ideas generated. These protocols are analysed and the results are categorised by performance, solutions or ideas.

Please keep in mind that not all the personas - as they are different characters - are going to act the same way in the same situation. You should therefore role-play several personas through the same scenario if it is central to more than one target group.

7. Use the findings to design/ improve the product or service

The categorised findings from role-playing the scenarios is used as input for designing new or improving existing offers. At this stage you have to make decisions which persona(s) the product or service will be optimised for or where reasonable compromises have to be made to meet the needs for more than one persona. This is always a question of balancing the pros and cons.

\section{CONCLUSION}

Visitor data plays a part of growing importance in museums. There is more data available than ever before but at the same time it remains a challenge to make this data useful and actionable and to process it in a way it becomes sharable and memorable, making it even more valuable. Up to now, there was a significant lack of tools to support this. The personas method appears to be an ideal 
instrument to step in and fill this gap. It provides a helpful communication tool to establish a shared understanding of visitors' needs within the institution and encourages the museum to design tailor-made offers matching these needs. This is done by creating data-based yet fictitious representations of target groups, the personas. Why would museums, with their thousands of visitors a year, need to create fictitious ones? Firstly, because personas are constructs, which implies making choices and thus being able to focus on the relevant characteristics to help reaching the goals. Secondly, because personas are available at all times, which makes them the best allies of the staff developing an offer or preparing a decision. Thirdly, because they fulfil their assignments without asking for anything in return. And last but not least, fourthly, because one persona stands for many, many more visitors.

\section{LITERATURE:}

A life of their own. Museum visitor personas penetrating the design lifecycle of a mobile experience. In Proceeding CHI EA 2013 CHI 2013 Extended Abstracts on Human Factors in Computing Systems. New York: ACM, 2013, pp. 547-552.

COOPER, Alan. The Inmates are Running the Asylum. Indianapolis: Sams, 1999. ISBN 0-672-31649-8.

GRUDIN, Jonathan. Why Personas Work: The Psychological Evidence. In PRUITT, John and Tamara ADLIN. The Persona Lifecycle. Keeping People in Mind Throughout Product Design. Amsterdam: Elsevier, 2006, pp. 642-663. ISBN 0-12-566251-3.

IACOVELLI, Stephanie. Using Personas in the Design Process of Digital Exhibit Interactives. Creating Museum Media for Everyone (DRL-1114549) [online]. Boston: Museum of Science, 2014 [accessed 2018-12-15]. Available from www: <http://openexhibits.org/wp-content/uploads/papers/CMME\%20 Personas.pdf $>$.
LEE, Ahree and Emily LYTLE-PAINTER. Getting Personal: Creating Personas for Museum Visitors. In The annual conference of Museums and the Web, April 8-11, 2015, Chicago, IL, USA [online]. [accessed 2018-12-15]. Available from www: <http://mw2015. museumsandtheweb.com/proposal/ getting-personal-creating-personas-for-museum-visitors/>.

MULDER, Steve and Ziv YAAR. The User is Always Right. A Practical Guide to Creating and Using Personas for the Web. Berkeley: New Riders, 2007. ISBN 0-13-279828-X.

NIELSEN, Lene. Personas - User Focused Design. London: Springer, 2013. ISBN 1-4471-4083-4.

NORMAN, Donald A. Ad-Hoc Personas and Empathetic Focus. Essay. [online]. 2008 [accessed 2018-12-15]. Available from www: < https://jnd.org/ad-hoc_ personas_empathetic_focus/ $>$.

NYSTRÖM, Viveca and Linnéa SJÖGREN. The persona method. In NYSTRÖM, Viveca and Linnéa SJÖGREN. An Evaluation of the Benefits and Value of Libraries. Oxford: Chandos, 2012, pp. 99-115. ISBN 1-84334-686-9.

PORTIGAL, Steve. Persona non-grata. In Interactions, January + February, 2008, pp. 72-73. ISSN 1072-5520.

PRUITT, John and Tamara ADLIN. The Persona Lifecycle. Keeping People in Mind Throughout Product Design. Amsterdam: Elsevier, 2006. ISBN 0-12-566251-3.

QUESENBERY, Whitney. Storytelling and Narrative. In PRUITT, John and Tamara ADLIN. The Persona Lifecycle. Keeping People in Mind Throughout Product Design. Amsterdam: Elsevier, 2006, pp. 520-554. ISBN 0-12-566251-3.

SCHUCK-WERSIG, Petra and Gernot WERSIG. Die Staatlichen Museen zu Berlin und ihre Besucher. Zusammenfassungen aus den Jahren 2001-2004 [The National Museums in Berlin and their visitors. Summaries from the years 2001-2004] (Mitteilungen und Berichte aus dem Institut für Museumskunde, Bd. 35). Berlin: Institut für Museumskunde, 2006. ISSN 1436-4166.

SCHWEIBENZ, Werner. Zielgruppenorientiertes Informationsdesign mit Personas. [Target-group-oriented Information Design using Personas]. Information - Wis- senschaft \& Praxis, 2004, vol. 55, no. 2, pp. 151-156. ISSN 1619-4292.

SCHWEIBENZ, Werner. Know thy visitors. Personas for visitor-centered museums. In The International Journal of the Inclusive Museum, 2008, vol. 1, no. 2, pp. 103-109. ISSN 1835-2014.

SLATIN, John M. and Sharron RUSH. Maximum Accessibility. Making your Web Site more usable for everyone. Boston: Addison-Wesley Professional, 2003. ISBN 0-201-77422-4.

SPELLERBERG, Marty, Elise GRANATA and Sarah WAMBOLD. Visitor-first, mobilefirst: Designing a visitor-centric mobile experience. In The annual conference of Museums and the Web, April 8-11, 2016, Los Angeles, CA, USA [online]. [accessed 2018-12-15]. Available from www: <http://mw2016.museumsandtheweb. com/paper/visitor-first-mobile-first-designing-a-visitor-centric-mobile-experience/ $>$.

TASICH, Tiana and Elena VILLAESPESA. Meeting the Real User: Evaluating the Usability of Tate's Website. In Museums and the Web 2013. Proceedings from the annual conference of Museums and the Web 2013. April 17-20, 2013, Portland, OR, USA [online]. Toronto, Ontario: Archives \& Museum Informatics [accessed 2018-12-15]. Available from www: <http://mw2013. museumsandtheweb.com/paper/ meeting-the-real-user-evaluating-the-usability-of-tates-website/>.

WENZEL, Mirjam. Towards an Online Platform for Jewish History and Culture. The mid-term online strategy of the Jewish Museum Berlin. In Blogerim. From the corridors of the Jewish Museum Berlin [online]. 2015 [accessed 2018-12-15]. Available from www: <http:// www.jmberlin.de/blog-en/2015/06/ online-platform/>.

WINTZERITH, Stéphanie. Streifzug durch die Welt der Besucherforschung. In Das Publikum im Blick. Besucherforschung als Impuls für besucherorientierte Museumsarbeit. Hagen:

Landschaftsverband Westfalen-Lippe, LWL Freilichtmuseum Hagen, 2014, pp. 44-57. ISBN 3-926190-31-0. 


\section{WERNER SCHWEIBENZ}

MusIS - MuseumsInformationsSystem, Bibliotheksservice-Zentrum Baden-

-Wuerttemberg

Universität Konstanz, Konstanz,

Bundesrepublik Deutschland

werner.schweibenz@uni-konstanz.de

Werner Schweibenz studied information science at the

University of Saarland,

Saarbrücken, and the University of Missouri-Columbia. Since 2007 he works for MusIS coordinating the digital object documentation of the State Museums of Baden-

-Wuerttemberg and the publication of online exhibits.

Werner Schweibenz studoval informatiku na Sárské univerzitě v Saarbrückenu a na Missourské univerzitě v Kolumbii. Od roku 2007 pracuje pro MusIS jako koordinátor digitální dokumentace předmětů v státních muzeích v Bádensku-Württembersku a publikace muzejních exponátů na internetu.

\section{STÉPHANIE WINTZERITH}

Wintzerith - Evaluation für Kultureinrichtungen, Karlsruhe, Bundesrepublik Deutschland

www.wintzerith.de swi@wintzerith.de

Stéphanie Wintzerith is carrying out evaluations and visitor studies for museums and other cultural institutions. Her PhD topic covered the international cooperation of museums and its intercultural dimension. She is working freelance with a strong focus on international project and is an active member of ICOM.

Stéphanie Wintzerith provádí evaluace a studie návštěvnosti pro muzea a jiné kulturní instituce. Téma její disertační práce se týkalo mezinárodní spolupráce muzeí a jejího mezikulturního rozměru. Pracuje na volné noze, zaměřuje se zejména na mezinárodní projekty a je aktivní členkou ICOM. 